\title{
Program "Mindful Parenting" untuk Meningkatkan Kesejahteraan Subjektif Ibu yang Memiliki Anak Retardasi Mental
}

\author{
Martaria Rizky Rinaldi', Sofia Retnowati ${ }^{2}$ \\ Fakultas Psikologi Universitas Gadjah Mada
}

\begin{abstract}
Parenting child with intellectual disability is associated with physical and psychological problems that influence mother's subjective well-being. The evidence is show that mindfulness based intervention can increase of life satisfaction, elicit positive affect, dan minimize negative affect, so that it can increase subjective well-being. The aim of this study is to examine the effectiveness of "Mindful parenting" program in increasing subjective well-being mother who has child with intellectual disability. This study uses a one-group pretest-posttesttt design using a double pretest. "Mindful Parenting" program was administered to ten mothers of children with intellectual disability. Participant attend 8 sessions of "Mindful parenting" program in four meeting. Analysis using Friedman test showed significance result $\left(\mathrm{F}_{\mathrm{r}(2)}=11.13, \mathrm{p}<0.05\right)$. It conclude that there was significant effect of "Mindful parenting" program on promotes subjective well-being of mothers of children with intellectual disability.
\end{abstract}

Keywords : intellectual disability, mindfulness, mindful parenting, subjective well-being

Abstrak. Mengasuh anak yang mengalami retardasi mental berhubungan dengan munculnya permasalahan fisik dan psikologis pada ibu. Hal ini mempengaruhi kesejahteraan subjektif ibu. Intervensi dengan berbasis mindfulness terbukti dapat membantu untuk meningkatkan kepuasan hidup, afek positif, dan menurunkan afek negatif sehingga kesejahteraan subjektif dapat meningkat. Penelitian ini bertujuan untuk menguji pengaruh program "Mindful Parenting" untuk meningkatkan kesejahteraan subjektif ibu yang memiliki anak retardasi mental. Penelitian ini menggunakan desain one-group pretest-posttest design using a double pretest. Pengukuran kesejahteraan subjektif dilakukan dengan menggunakan skala kesejahteraan subjektif. Program "Mindful Parenting" diikuti oleh sepuluh ibu yang memiliki anak retardasi mental. Partisipan mengikuti mengikuti delapan sesi program "Mindful parenting" dalam empat kali pertemuan. Analisis dengan menggunakan uji Friedman menunjukkan hasil yang signifikan $\left(F_{r(2)}=11,13, p<0,05\right)$. Hal ini menunjukkan bahwa program "Mindful Parenting" dalam penelitian ini terbukti dapat meningkatkan kesejahteraan subjektif ibu yang memiliki anak dengan retardasi mental.

Kata kunci: kesejahteraan subjektif, mindfulness, mindful parenting, retardasi mental,

Jumlah penyandang disabilitas terus meningkat dari tahun ke tahun. Hasil analisis

${ }^{1}$ Korespondensi mengenai isi artikel ini dapat dilakukan melalui : martaria.rizky.r@ugm.ac.id

2 Atau melalui sofia_53@ugm.ac.id dari WHO tahun 2004 menunjukkan bahwa sekitar 978 juta penduduk dunia mengalami disabilitas sedang dan sekitar 185 juta mengalami disabilitas parah (WHO, 2011). Di Indonesia sendiri, 
berdasarkan SUSENAS (Survei Sosial Ekonomi Nasional) tahun 2012 penyandang disabilitas yaitu sekitar 6,05 juta jiwa (Kemkes RI, 2014). Jenis disabilitas yang terjadi yaitu keterbatasan melihat, mendengar, berjalan atau naik tangga, mengingat atau berkonsentrasi atau berkomunikasi dan kesulitan mengurus diri. Khususnya anak, pada tahun 2013 diperkirakan jumlah penyandang disabilitas yaitu sekitar 4,2 juta anak (BKKBN, 2013).

Memiliki anak yang sehat dan normal merupakan harapan setiap keluarga, terutama ibu. Hampir semua ibu takut jika memiliki anak yang cacat dan tidak sempurna (Bernstein, 1990). Penelitian dari Reichman, Corman, dan Noonan (2008) menunjukkan bahwa terdapat dampak positif dan negatif dari hadirnya anak dengan disabilitas dalam sistem keluarga. Dampak positifnya yaitu akan memperluas wawasan, meningkatkan kepekaan terhadap kekuatan batin, meningkatkan kebersamaan keluarga, dan mendorong hubungan dengan komunitas atau institusi keagamaan. Dampak negatifnya yaitu meningkatkan waktu perawatan dan pengeluaran dalam keluarga, menyebabkan tuntutan fisik dan emosi, dan perlunya penyediaan kebutuhan yang berhubungan dengan membesarkan anak dengan disabilitas. Dampak yang terjadi tergantung pada kondisi dan tingkat keparahan, seperti kondisi fisik, emosi, dan finansial yang diperlukan, serta ketersediaan sumber daya dalam keluarga.

Dalam penelitian ini, disabilitas difokuskan pada retardasi mental. Dalam DSM-5 (American Psychiatric Association, 2013) dijelaskan retardasi mental adalah disabilitas yang memiliki karakteristik kurangnya fungsi kognitif dan perilaku adaptif yang meliputi kemampuan sosial dan ketrampilan praktis sehari-hari.
Disabilitas ini munculnya pada usia di periode perkembangan.

Anak dengan retardasi mental mengalami berbagai permasalahan, antara lain perilaku agresif, perilaku melukai diri sendiri, perilaku stereotip, gangguan kecemasan, gangguan mood, permasalahan makan, dan permasalahan tidur (Sturmey \& Didden, 2014). Permasalahan yang terjadi pada anak memberikan dampak juga terhadap keluarga. Perilaku dan permasalahan pada anak membuat ibu membutuhkan waktu yang lebih banyak dalam perawatan (Schieve, Boulet, Kogan, Van NaardenBraun, \& Boyle, 2011). Hal ini membuat perilaku dan beban pengasuhan anak berpengaruh signifikan terhadap kesehatan fisik dan psikologis yang merawatnya (Diwan, Chovatiya, \& Diwan, 2011). Orang tua dari anak dengan retardasi mental memiliki kondisi kesehatan yang lebih buruk (Perkins \& Hewitt, 2014).

Penelitian menunjukkan terdapat dampak yang besar terhadap aspek keuangan dan pekerjaan pada orang tua dengan anak disabilitas (Kogan et al., 2008). Hal ini dikarenakan orang tua mengeluarkan banyak biaya, terutama jika merawat anak dengan disabilitas yang berat (Anderson, Dumont, Jacobs, \& Azzaria, 2007). Waktu perawatan yang besar membuat orang tua berhenti bekerja (Schieve et al., 2011).

Kesehatan mental dari orang tua anak yang mengalami retardasi mental pun lebih buruk daripada orang tua anak tanpa retardasi mental (Totsika, Hastings, Emerson, Berridge, \& Lancaster, 2011). Hal ini dikarenakan orang tua dan keluarga dari anak yang mengalami retardasi mental mengalami situasi yang lebih stres dan menguras emosi dalam kehidupan sehari-hari (Baker et al., 2003; Neece \& Baker, 2008). Ibu dari anak retardasi 
mental juga cenderung lebih berisiko mengembangkan depresi (Singer, 2006).

Adanya anak yang mengalami retardasi mental dalam keluarga memberikan pengaruh yang berbeda terhadap ayah dan ibu, dikarenakan adanya perbedaan peran dalam keluarga. Perempuan memiliki tanggung jawab yang lebih besar dalam pengasuhan (Olsson \& Hwang, 2001). Peran jenis kelamin jelas terbukti berpengaruh dalam proses pengasuhan anak yang mengalami retardasi mental, ibu cenderung lebih mengalami stres dan tingkat kecemasan yang tinggi (Norlin \& Broberg, 2013; Seymour, Wood, Giallo, \& Jellett, 2013). Selain lebih mengalami stres, ibu juga mengalami permasalahan emosi, kurangnya tidur, dan rasa bersalah (Burke \& Hodapp, 2014; Findler, Klein Jacoby, \& Gabis, 2016; Glenn, Cunningham, Poole, Reeves, \& Weindling, 2009; Lee, 2013). Berdasarkan fenomena tersebut, maka penelitian ini lebih berfokus pada ibu yang memiliki anak retardasi mental.

Beban ekonomi, psikologis dan sosial dalam merawat anak dengan retardasi mental sangat mempengaruhi kualitas hidup orang tua (Isa et al., 2013). Keluarga yang mengasuh anak dengan permasalahan perkembangan, termasuk retardasi mental memiliki kualitas hidup yang lebih rendah (Gardiner \& Iarocci, 2012). Kualitas hidup merupakan penilaian evaluatif berdasarkan indikator objektif dan/atau subjektif dari fisik, kognitif, keadaan emosi dan kehidupan sosial seseorang dalam berbagai konteks (Costanza et al., 2008). Pada tingkat individual, kesejahteraan subjektif merupakan indikator dari kualitas hidup seseorang (Efklides \& Moraitou, 2013). Para penyusun teori dan peneliti merekomendasikan untuk berfokus pada aspek subjektif dari kualitas hidup (Cummins et al., 2010). Diener (2000) mendefinisikan kesejahteraan subjektif sebagai evaluasi umum dari kualitas hidup seseorang yang terdiri dari tiga komponen, yaitu (1) penilaian kognitif tentang bagaimana kehidupannya (kepuasan hidup); (2) pengalaman emosi positif yang tinggi; dan (3) pengalaman emosi negatif yang rendah.

Ibu dari anak yang mengalami gangguan perkembangan memiliki tingkat kesejahteraan subjektif yang berada di bawah rata-rata (Werner \& Shulman, 2013) dan cenderung rendah dibandingkan pada ayah dan pada ibu yang tidak memiliki anak yang mengalami retardasi mental (Olsson \& Hwang, 2001; Olsson \& Hwang, 2006). Beban yang terjadi karena pengasuhan anak yang mengalami gangguan perkembangan menyebabkan terjadinya risiko rendahnya kesejahteraan subjektif dari pengasuhnya (terutama ibu). Intervensi untuk meningkatkan kesejahteraan dari orang tua perlu dilakukan (Baker, Blacher, \& Olsson, 2005).

Terdapat beberapa jenis intervensi yang telah terbukti dapat meningkatkan kesejahteraan subjektif, antara lain Happiness Training Program yang disusun oleh Michael Fordyce (Compton \& Hoffman, 2013), emphatic love therapy (Rosada, 2015), pelatihan berbasis pendekatan rasional emotif (Dewanto, 2015), dan terapi pemaafan (Tyas, 2013). Lebih lanjut, intervensi kebersyukuran (Jackowska, Brown, Ronaldson, \& Steptoe, 2015) dan program psikoedukasi mengenai permasalahan anak (Duran \& Barlas, 2016) juga dapat meningkatkan kesejahteraan subjektif.

Kesejahteraan subjektif merupakan konsep yang mencakup mengalami afek positif (menyenangkan), rendahnya tingkat afek negatif (tidak menyenangkan), dan tingginya kepuasan hidup (Diener, Lucas, \& Oishi, 2005). 
Kondisi ibu yang memiliki anak dengan retardasi mental mengalami kesejahteraan subjektif yang rendah. Hal ini berarti ibu sedikit mengalami afek positif, tingginya tingkat afek negatif, dan rendahnya kepuasan hidup. Usaha yang dapat dilakukan untuk meningkatkan kesejahteraan subjektif yaitu dengan meningkatkan kepuasan hidup dan pengalaman afek positif, dan menurunkan pengalaman afek negatif.

Mengungkapkan kebersyukuran dapat meningkatkan kepuasan hidup (Boehm, Lyubomirsky, \& Sheldon, 2011) dan menurunkan afek negatif (Emmons \& McCullough, 2003). Selain itu, mindfulness dapat meningkatkan emosi positif dan fleksibilitas dalam merespon, menurukan reaktivitas pikiran dan emosi, dan menurunkan afek negatif dan rumination (David \& Hayes, 2011 dalam Malaktaris, Lemons, Lynn, \& Condon, 2015).

Kabat-Zinn (1994) menjelaskan bahwa mindfulness adalah keadaan seseorang yang orang dapat memberikan perhatian tanpa terganggu pada suatu periode waktu, dengan tidak memberikan penilaian terhadap keadaan fisik, kognitif, dan pengalaman psikologis yang sedang berlangsung. Dalam keadaan mindful, orang tidak memberikan analisis kritis atau memberikan penilaian terhadap pengalaman yang dialami. Mindfulness berfokus pada perhatian yang berkesinambungan pada pengalaman yang mencakup peristiwa internal maupun eksternal (Brown \& Ryan, 2003; Brown, Ryan, Creswell, 2007; Kabat-Zinn, 1990). Pada mindfulness terdapat proses pengamatan kembali yang merujuk pada kapasitas seseorang untuk mengambil jarak pada pikiran dan emosinya (Shapiro, Carlson, Austin, \& Freedman, 2006). Hal ini mencakup perpindahan proses sadar individu. Individu yang awalnya kurang mengidentifikasi peristiwa mental (seperti pikiran dan emosi) menjadi lebih menyadari peristiwa tersebut. Individu yang lebih menyadari peristiwa (memiliki kesadaran yang tinggi) cenderung memiliki kondisi emosional yang positif.

Pengaruh mindfulness terhadap afek dijelaskan dengan tiga fungsi spesifik, yaitu menurunkan afek negatif, meningkatkan afek positif, dan mengubah respon individu jika mengalami afek negatif (Shapiro \& Carlson, 2009). Program MBSR (Davidson et al., 2003) dapat meningkatkan aktivasi otak depan kiri. Area ini berhubungan dengan afek positif. Penelitian Cresswell, Way, Eisenberger, \& Lieberman (2007) terhadap pengaruh neurologis mindfulness menunjukkan bahwa individu yang memiliki skor mindfulness yang tinggi, lebih tidak reaktif terhadap stimulus yang menakutkan secara emosional dibandingkan dengan individu yang memiliki skor rendah. Hal ini diindikasikan oleh respon amigdala yang melemah dan peningkatan aktivasi prefrontal cortex (PFC) saat menghadapi stimulus. Amigdala merupakan bagian otak yang berfungsi mengirimkan peringatan adanya bahaya ataupun ancaman, sehingga dapat menyebabkan emosi negatif. PFC merupakan bagian otak yang berhubungan dengan fungsi yang lebih tinggi, seperti kesadaran, konsentrasi dan pengambilan keputusan. PFC bertugas menghalangi pesan yang dikirim oleh amigdala, sehingga tidak menimbulkan reaktivitas emosi negatif terhadap suatu stimulus. Individu yang mindful memiliki reaktivitas afek negatif yang lebih rendah dan afek positif yang lebih stabil dibandingkan individu yang tidak mindful ketika dihadapkan pada suatu stimulus yang negatif (Arch \& Craske, 2006).

Mindfulness dapat ditingkatkan
dengan meditasi atau pelatihan
mindfulness (Baer, Smith, Hopkins,


Krietemeyer, \& Toney, 2006; Falkenstrom, 2010). Praktik mindfulness dibagi menjadi dua kategori, yaitu praktik formal dan informal (Germer, Siegel, \& Fulton, 2005; Shapiro \& Carlson, 2009). Terdapat empat jenis terapi yang menerapkan konsep mindfulness, yaitu Mindfulness-Based Stress Reduction (MBSR), Mindfulness-Based Cognitive Therapy (MBCT), Dialectical Behavior Therapy (DBT), dan Acceptance and Commitment Therapy (ACT) (Germer et al., 2005). Intervensi dengan mindfulnes berpengaruh terhadap kondisi emosi individu (Weinstein, Brown, \& Ryan, 2009) yang merupakan indikator kondisi wellbeing (Bishop, 2002; Weinstein et al, 2009). Program mindfulness MBSR (Bazzano et al., 2013) kepada orang tua dari anak yang mengalami developmental disability (intelectual disability, autisme, cerebral palsy, epilepsi dan kondisi lain yang terkait) menunjukkan efektifitasnya dalam menurunkan stres pada stres pengasuhan. Orang tua juga mengalami peningkatan dalam kemampuan mindfulness, selfcompassion, dan well-being. Selain itu, program mindfulness juga dapat meningkatkan kemampuan mengatasi masalah sehari-hari yang berkaitan dengan ketidakbahagiaan hidup (Grossman, Niemann, Schmidt, \& Walach, 2004).

Berdasarkan hasil penelitian di Iran, mindfulness berbasis kognitif terapi (MBCT) dapat meningkatkan kehidupan psikososial pada keluarga dengan anak yang mengalami cerebral palsy (Barog, Younesi, Sedaghati, \& Sedaghati, 2015). Selain itu, MBCT juga dapat menurunkan depresi dan kecemasan yang diakibatkan oleh lingkungan yang penuh stres (Kaviani, \& Hatami, 2011; Menranfar, Younesi, \& Banihashem, 2012).

Mindfulness telah terbukti dapat membantu mengatasi masalah kesehatan mental. Membawa mindfulness ke dalam pengasuhan (parenting) merupakan salah satu aplikasi dari mindfulness. Mindful parenting merupakan sebuah program yang merupakan adaptasi dari MBSR dan MBCT untuk ibu belajar menerapkan ketrampilan untuk dirinya sendiri dan untuk pengalamannya dalam merawat anak (Bögels \& Restifo, 2014).

Konsep utama dalam mindful parenting yaitu (1) kesadaran yang lebih besar pada dunia, perasaan, dan kebutuhan anak yang unik; (2) kemampuan yang lebih besar untuk hadir dan mendengarkan dengan penuh perhatian; (3) menyadari dan menerima apapun di setiap saat, baik menyenangkan ataupun tidak menyenangkan; (4) menyadari impuls reaktif pada diri dan belajar untuk merespon secara tepat dengan kejernihan dan kebaikan hati (Bogels \& Restifo, 2013). Orang tua yang mempraktikkan mindful parenting pada interaksinya dengan anak akan lebih tenang menghadapi perilaku negatif anak (Bogels, Lehtonen, \& Restifo, 2010), lebih konsisten dan mempunyai tujuan serta nilai yang jelas dalam pengasuhan (Duncan et al, 2009). Mindful parenting juga meningkatkan interaksi positif antara orang tua dan anak, meningkatkan afek positif, dan menurunkan afek negatif, meningkatkan kepercayaan orang tua, dan meningkatkan kemampuan berbagi perasaan (Coastsworth, Duncan, Greenberg, \& Nix, 2010; Duncan et al, 2009; Singh et al, 2007; Singh et al, 2009). Selain itu, mindful parenting dapat menjaga hubungan emosi dan fisik antara orang tua dan anak (Almaier, \& Maloney, 2007), meningkatkan fungsi orang tua dalam pengasuhan anak (Bogels et al., 2010), penerimaan positif (MacDonald et al., 2010), kepuasan orang tua (Singh, et al., 2007; Singh et al., 2009), dan kebahagiaan pengasuhan (Singh et al., 2009).

Program "Mindful Parenting" dalam 
penelitian ini menggunakan modalitas kelompok yang memfasilitasi dukungan kelompok, kondisi suportif, dan kohesivitas kelompok (Berg, Landreth, \& Fall, 2006). Intervensi yang berbasis mindfulness biasanya diberikan dalam kelompok dengan jumlah peserta 8 sampai 12 orang. Kelebihan dari format kelompok yaitu memberikan kesempatan kepada peserta untuk belajar observasional, mendapatkan dorongan dan dukungan emosi, rasa kemanusiaan dan perspektif yang leih luas terhadap permasalahan serta meningkatkan motivasi untuk melakukan praktik rumah (Schroevers, Tovote, Snippe, \& Fleer, 2016). Manfaat lain dari setting kelompok yaitu memfasilitatsi adanya insight dan empati dari partisipan lain (Lane, Goodrich, \& Miller, 2015)

Pelatihan mindful parenting dalam penelitian ini terdiri dari delapan sesi yang disusun berdasarkan panduan mindful parenting yang disusun oleh (Bogels \& Restifo, 2014). Setiap sesinya terdiri dari tema yang berkaitan dengan ketrampilan mindfulness dan aplikasinya dalam pengasuhan anak. Penelitian ini bertujuan mengetahui apakah program "Mindful parenting" dapat meningkatkan kesejahteraan subjektif ibu yang memiliki anak retardasi mental. Hipotesis yang diajukan dalam penelitian ini yaitu program "Mindful parenting" dapat meningkatkan kesejahteraan subjektif ibu yang memiliki anak dengan retardasi mental.

\section{Metode}

\section{Partisipan Penelitian}

Partisipan dalam penelitian ini melibatkan 10 orang ibu yang memiliki anak retardasi mental. Karakteristik dari partisipan yaitu sebagai berikut: (1) Ibu yang memiliki anak dengan retardasi mental, yang E-JURNAL GAMA JPP tergabung dalam komunitas orang tua yang memiliki anak berkebutuhan khusus, (2) Ibu merupakan pengasuh utama anak dan tinggal bersama dengan anak yang mengalami retardasi mental, (3) Mampu melakukan mobilisasi secara memadai untuk bergabung dalam proses intervensi, (4) Mampu berbahasa Indonesia dengan baik secara lisan dan tertulis

Kriteria inklusi dari penelitian ini yaitu partisipan bersedia berpartisipasi dalam proses penelitian dan memenuhi hak serta kewajiban sebagai subjek penelitian yang dibuktikan dengan kesediaannya untuk mengisi informed consent penelitian ini.

\section{Instrumen Penelitian}

Instrumen yang digunakan dalam penelitian ini antara lain: lembar persetujuan (informed consent), skala kesejahteraan subjektif, modul intervensi, panduan dan lembar observasi umum partisipan, lembar evaluasi program "Mindful parenting, buku catatan kegiatan dan buku harian.

Skala kesejaheraan subjektif yang digunakan dalam penelitian ini merupakan modifikasi dari skala kesejahteraan subjektif yang disusun oleh Utami (2009). Koefisien reliabilitas skala afek positif $r=0,937$, afek negatif $r=0,954$, dan kepuasan hidup $r=0,807$. Skala ini memiliki reliabilitas skor komposit dengan koefisien reliabilitas $r=0,968$.

Modul intervensi yang digunakan dalam penelitian ini merupakan modifikasi dari panduan mindful parenting untuk praktisi kesehatan mental (Bogels \& Restifo, 2014). Peneliti memodifikasi kegiatan berdasarkan tema setiap sesi dan menyesuaikan dengan tujuan penelitian serta kebutuhan partisipan penelitian. Modul program "Mindful parenting" terdiri dari delapan sesi kegiatan, materi setiap sesinya dan instruksi yang diperlukan 
oleh fasilitator.

Alat ukur yang digunakan untuk cek manipulasi yaitu skala mindful parenting. Skala mindful parenting disusun oleh peneliti berdasarkan konsep mindful parenting.

Hasil analisis melalui rumus Aiken's $\mathrm{V}$ menunjukkan nilai $\mathrm{V}$ untuk Modul "Mindful Parenting" memiliki rerata 0,79. Hal ini menunjukkan bahwa modul memiliki validitas isi yang baik. Berdasarkan data hasil cek manipulasi dengan menggunakan skala mindful parenting pada uji coba, analisis Wilcoxon signed rank test menunjukkan $\mathrm{z}=-2,023, \mathrm{p}=$ 0,021 . Hal ini menunjukkan bahwa terdapat perbedaan yang signifikan antara hasil pengukuran skala mindful parenting sebelum dan sesudah diberikan Program "Mindful Parenting" pada partisipan uji coba.

Panduan dan lembar observasi digunakan oleh observer sebagai panduan untuk mengamati partisipan dalam proses intervensi berdasarkan aspek yang perlu diamati. Observer juga memberikan penilaian keberhasilan intervensi berdasarkan indikator tujuan intervensi yang telah ditetapkan oleh peneliti.

Lembar evaluasi diisi oleh partisipan penelitian untuk mengetahui keberhasilan intervensi berdasarkan persepsi partisipan. Lembar evaluasi juga berisi penilaian partisipan terhadap manfaat pelatihan dan proses pelaksanaan program.

Buku catatan kegiatan disusun oleh peneliti sesuai dengan sesi yang ada. Buku ini digunakan untuk pencatatan tugas yang perlu dilakukan oleh partisipan pada saat proses pelatihan

Buku harian disusun dengan tujuan untuk melihat perkembangan partisipan setiap harinya selama mengikuti program. Buku ini berisi pencatatan latihan pada saat di luar proses pelatihan (tugas rumah). Dalam buku harian juga berisi skala ukur diri mindful parenting dan skala ukur diri emosi harian.

\section{Desain Penelitian}

Penelitian ini menggunakan pendekatan kuantitatif dengan desain eksperimen "the one group pretest-posttesttt design using a double pretest" (Shadish, Cook, \& Campbell, 2002). Peneliti hanya menggunakan kelompok eksperimen yaitu kelompok yang menerima intervensi program Mindful parenting. Hal ini dikarenakan terbatasnya subjek penelitian yang dapat mengikuti seluruh rangkaian kegiatan pelatihan. Penggunaan double pretest yaitu untuk mengurangi ancaman maturitas dan regresi (Shadish, Cook, \& Campbell, 2002).

\section{Intervensi}

Program "Mindful parenting" merupakan intervensi berbasis mindfulness yang diaplikasikan dalam pengasuhan. Program dilaksanakan dalam empat kali pertemuan dengan durasi sekitar 180 menit selama dua minggu.

\section{Analisis Data}

Proses analisis data pada penelitian ini dilakukan dengan menggunakan uji Friedman. Uji Friedman dilakukan dengan membandingkan lebih dari dua sampel yang berhubungan (Corder \& Foreman, 2009). Analisis data dilengkapi dengan analisis deskriptif berupa hasil observasi dan wawancara dari partisipan penelitian serta hasil buku catatan kegiatan dan buku harian partisipan untuk mengetahui perkembangan partisipan dalam program.

\section{Hasil}

\section{Analisis Kuantitatif}

Uji cek manipulasi

Berdasarkan hasil uji beda terhadap skor E-JURNAL GAMA JPP 
pretest pertama dan pretest kedua dengan menggunakan Wilcoxon signed rank-test diperoleh nilai $Z=-0,716$ dengan $p=0,237$. Hal ini mengindikasikan bahwa tidak terdapat perbedaan pada keadaan atau ketrampilan mindful parenting sebelum diberikannya intervensi "Mindful parenting". Berdasarkan hasil uji beda terhadap skor pretest kedua dan posttest dengan menggunakan Wilcoxon signed rank-test diperoleh nilai $Z=-2,670$ dengan $p$ $=0,004$. Hal ini mengindikasikan bahwa terdapat perbedaan keadaan atau ketrampilan mindful parenting antara sebelum dan sesudah diberikannya program "Mindful parenting".

\section{Uji Hipotesis}

Berdasarkan hasil uji Friedman menunjukkan hasil yang signifikan $\left(F_{r(2)}=\right.$ $11,13, p=0,02)$. Hal ini menunjukkan perbedaan antara skor kesejahteraan subjektif partisipan pada pretest 1 , pretest 2 , dan posttest.

Analisis dengan Wilcoxon signed rank-test terhadap pretest pertama dengan pretest kedua menunjukkan tidak terdapat perbedaan yang signifikan $(Z=-1,244$ dengan $\mathrm{p}=0,107)$. Hasil tersebut menunjukkan bahwa tanpa diberikan perlakuan, kesejahteraan subjektif ibu yang memiliki anak retardasi mental tidak dapat meningkat.

Hasil analisis Wilcoxon signed ranktest terhadap skor kesejahteraan subjektif pada pretest kedua dan posttest menunjukkan bahwa terdapat perbedaan yang signifikan $(\mathrm{Z}=-2,497$ dengan $\mathrm{p}=$ 0,006). Hasil tersebut berarti program "Mindful parenting" dapat meningkatkan kesejahteraan subjektif ibu yang memiliki anak retardasi mental.

Hasil pengukuran effect size menunjukkan $r=0,558$ yang berarti terdapat efek yang besar (Field, 2009). Hasil tersebut menunjukkan bahwa program "Mindful parenting" memberikan efek yang besar terhadap kesejahteraan subjektif ibu yang memiliki anak dengan retardasi mental.

Peneliti juga melakukan analisis tambahan pada aspek kesejahteraan subjektif. Peneliti melakukan analisis tiap aspek untuk mengetahui aspek apa yang mengalami perubahan signifikan setelah diberikannya perlakuan. Berdasarkan analisis dengan Wilcoxon Signed Ranks Test pada skor kepuasan hidup menunjukkan hasil yang tidak signifikan $(Z=-1,411, p=$ 0,079). Pada aspek afek positif menunjukkan hasil yang signifikan $(\mathrm{Z}=$ 2,312, $p=0,01)$ dan pada afek negatif menunjukkan hasil yang signifikan $(\mathrm{Z}=$ 2,805, $\mathrm{p}=0,05)$. Berdasarkan hasil analisis terhadap aspek dari kesejahteraan subjektif dapat disimpulkan bahwa terjadi peningkatan yang signifikan pada aspek afek positif dan afek negatif.

\section{Diskusi}

Tujuan dari penelitian ini yaitu untuk mengetahui apakah program "Mindful parenting" dapat meningkatkan kesejahteraan subjektif ibu yang memiliki anak retardasi mental. Hasil penelitian ini menunjukkan bahwa terjadi perubahan skor kesejahteraan subjektif pada saat sebelum dan sesudah diberikan perlakuan dengan nilai. Hasil pengukuran effect size menunjukkan terdapat efek yang besar. Hasil tersebut menunjukkan bahwa program "Mindful parenting" memberikan efek yang besar terhadap kesejahteraan subjektif ibu yang memiliki anak dengan retardasi mental.

Hasil penelitian ini membuktikan bahwa program "Mindful parenting" efektif meningkatkan kesejahteraan subjektif. Temuan penelitian ini senada dengan penelitian Hanley, Warner \& Garland (2015) yang menemukan bahwa individu 
yang melakukan meditasi mindfulness memiliki tingkat kesejahteraan subjektif yang lebih tinggi dibandingkan dengan individu yang tidak melakukan meditasi mindfulness.

$\begin{array}{llr}\text { Program } & \text { "Mindful } & \text { parenting" } \\ \text { memberikan } & \text { pengaruh } & \text { terhadap } \\ \text { kesejahteraan } & \text { subjektif } & \text { partisipan. }\end{array}$

Peningkatan skor kesejahteraan subjektif dari partisipan dalam penelitian ini dipengaruhi oleh munculnya kesadaran partisipan terhadap kondisi di sini dan saat ini (here and now). Hal ini membuat terjadinya proses pengamatan kembali terhadap peristiwa yang terjadi sehingga orang mampu untuk mengambil jarak pada pikiran dan emosinya (Shapiro, Carlson, Austin, \& Freedman, 2006) sehingga individu menjadi lebih menyadari peristiwa yang terjadi. Hasil penelitian ini menunjukkan bahwa mindfulness memiliki manfaat bagi ibu yang memiliki anak dengan retardasi mental. Hasil ini sesuai dengan penelitian Singh et al. (2006, 2007).

Aspek dari kesejahteraan subjektif yang mengalami perubahan secara signifikan dalam penelitian ini yaitu peningkatan afek positif dan penurunan afek negatif. Afek positif memiliki hubungan dalam faktor kepribadian ekstraversi (Compton \& Hoffman, 2013). Tingginya afek positif digambarkan sebagai keadaan penuh dengan konsentrasi, individu waspada, penuh energi dan terlibat penuh terhadap suatu kegiatan (Watson, Clark, \& Tellegen, 1988). Kondisi ini bersesuaian dengan kondisi yang melekat pada mindfulness, yaitu penuh konsentrasi pada keadaan saat ini (present moment) dan terlibat pada pengalaman saat ini (Kabat-Zinn, 2013).

Afek negatif menunjukkan bahwa seseorang mengalami berbagai suasana hati yang tidak menyenangkan, seperti tertekan, merasa bersalah, atau marah. Hal ini berhubungan dengan kepribadian neuroticism (Compton \& Hoffman, 2013). Tingginya afek negatif yang terjadi pada individu membuat individu merasakan emosi negatif (Diener, 2009). Hal ini berbeda dengan individu yang berada pada kondisi mindful. Individu yang mindful memiliki kemampuan yang lebih besar dalam mentoleransi pikiran, emosi dan pengalaman (Baer, 2003). Kemampuan toleransi yang meningkat membuat partisipan mengalami penurunan afek negatif secara signifikan.

Praktik mindfulness yang dilakukan membuat partisipan memiliki kesadaran yang lebih terhadap suatu pengalaman. Individu yang lebih menyadari peristiwa (memiliki kesadaran yang tinggi) cenderung memiliki kondisi emosional yang positif. Mindfulness memiliki pengaruh terhadap perkembangan kecerdasan emosi. Hal ini membuat individu dapat menerima emosi dengan lebih tepat dan dapat meregulasi emosi dengan efektif sehingga dapat meningkatkan kepuasan hidupnya (Caffey \& Hartman, 2008; Caffey, Hartman, Fredrickson, 2010; Schutte \& Malouf, 2011; Wang \& Kong, 2013). Fredrickson (dalam Brown, 2015) menjelaskan bahwa kondisi emosional yang positif dapat meningkatkan kemampuan dalam memproses dan menyimpan informasi baru, dan untuk membuat pola pikiran sehingga individu menjadi lebih positif dan kreatif.

Sepuluh dari sebelas partisipan dapat mengikuti proses intervensi dari awal hingga selesai. Hal ini termasuk salah satu keberhasilan fasilitator sebagai pemimpin kelompok. Pemimpin kelompok memiliki tugas untuk membuat dan mempertahankan kelompok (Yalom \& Leszcz, 2005). Dalam proses intervensi juga terjadi hubungan yang positif antara partisipan dengan fasilitator. Penelitian 
menunjukkan bawa hubungan yang positif sangat penting dalam munculnya perubahan positif pada klien (Burlingame \& Fuhriman dalam Corey, Corey, \& Corey, 2013).

Proses intervensi yang berlangsung juga melibatkan adanya proses terapeutik kelompok. Faktor terapeutik yang terjadi dalam proses intervensi yaitu kepercayaan, keterbukaan, saranan katarsis, umpan balik dalam kelompok, harapan yang baru, kepedulian dan penerimaan, komitmen untuk berubah, humor dalam kelompok, kohesivitas, rasa kebersamaan, dan penyampaian informasi (Yalom \& Leszcz, 2005; Corey \& Corey, 2014). Faktor-faktor tersebut yang membuat intervensi berjalan dengan kondusif dan memberikan pengaruh positif bagi partisipan.

Keseluruhan partisipan dan tim peneliti yaitu fasilitator, co-fasilitator dan observer berjenis kelamin perempuan. Partisipan tampak merasa nyaman dan dapat terbuka dalam proses intervensi, partisipan dapat menceritakan pengalamannya dan tampak tidak segan ketika berbicara sambil menangis. Bahkan salah satu partisipan, menangis tersedusedu ketika sedang meditasi bersyukur. Kesamaan jenis kelamin dapat meningkatkan kepuasan klien dalam proses terapeutik (Johnson \& Caldwell, 2010).

Dalam menghadiri pertemuan, beberapa partisipan tampak bermasalah dengan ketepatan waktu. Hal ini ditunjukkan dengan keterlambatan partisipan ketika menghadiri pertemuan sehingga waktu pelaksanaan menjadi mundur. Keadaan ini dimungkinkan karena permasalahan yang dialami oleh anak retardasi mental. Perilaku dan permasalahan pada anak membuat ibu membutuhkan waktu yang lebih banyak dalam perawatan (Padeliadu, 1998;
Schiece, Bouler, Kogan, Van NaardenBraun, \& Boyle, 2011) sehingga partisipan kesulitan untuk datang tepat waktu untuk menghadari pertemuan yang dilakukan pada pagi hari.

Partisipan penelitian memberikan evaluasi yang sangat baik terhadap kejelasan dan pemahaman instruksi serta pada kebermanfaatan materi. Evaluasi dalam penelitian ini dilakukan dengan memberikan rating pada masing-masing kegiatan. Pengisian dengan cara seperti ini memiliki keteratasan dalam penggalian respon, seperti dengan berpura-pura baik (faking good) (Stone et al., 2009). Meskipun demikian, berdasarkan observasi dari observer menunjukkan bahwa partisipan tampak mengikuti instruksi dengan baik.

Penelitian ini tidak terlepas dari ancaman-ancaman penelitian. Ancaman terhadap validitas internal pada penelitian ini yaitu testing. Dalam penelitian ini terjadi pengulangan pengukuran, yaitu pretest pertama, pretest kedua dan posttest dengan alat ukur yang sama meskipun dengan penyajian yang berbeda. Partisipan menyadari bahwa skala yang digunakan merupakan skala yang sama, sehingga performa partisipan dapat meningkat (Shadish et al, 2002)

Ancaman validitas tidak hanya pada validitas internal, namun juga pada validitas kesimpulan statistik. Ancaman pada validitas penyimpulan statistik yaitu unreliability of tratment implementation yang dilihat berdasarkan evaluasi buku harian partisipan. Partisipan penelitian tidak melakukan semua latihan meditasi mindfulness di rumah. Selain itu, partisipan juga tidak rutin mengaplikasikan mindful parenting dalam pengasuhan. Hal ini dapat menurunkan effect size (Shadish et al., 2002).

Keterbatasan dalam penelitian ini yaitu (1) penggunaan skala yang sama untuk tiga kali pengukuran, sehingga 
dimungkinkan ada proses belajar, dan (2) kurangnya kontrol yang kuat terhadap proses praktik mindfulness di rumah, sehingga tidak semua partisipan melakukan praktik mindfulness di rumah, (3) instrumen dalam penelitian membutuhkan kesediaan waktu, terutama dalam pengisian buku harian. Partisipan tidak mengisi buku harian secara rutin karena latar belakang partisipan sebagai ibu yang memiliki anak retardasi mental. Hal ini dikarenakan partisipan memiliki keterbatasan waktu untuk mengisinya.

\section{Kesimpulan}

Program "mindful parenting" dapat meningkatkan kesejahteraan subjektif ibu yang memiliki anak retardasi mental. Dengan demikian, hipotesis dalam penelitian ini dapat diterima. Tujuan utama dari program ini yaitu ibu yang memiliki anak dengan retardasi mental dapat memiliki kesadaran yang lebih besar pada dunia, perasaan, dan kebutuhan anak yang unik; mampu untuk hadir dan mendengarkan anak dengan penuh perhatian; menyadari dan menerima apapun di setiap saat, baik menyenangkan ataupun tidak menyenangkan; dan menyadari impuls reaktif pada diri dan belajar untuk merespon secara tepat. Tujuan ini telah dapat dirasakan oleh partisipan penelitian.

Berdasarkan analisis tambahan, disimpulkan bahwa aspek kesejahteraan subjektif pada partisipan yang mengalami perubahan secara signifikan yaitu aspek afek positif dan afek negatif. Hal ini tidak terlepas dari peningkatan kemampuan mindfulness yang signifikan pada partisipan. Kegiatan mindfulness berfokus pada keadaan saat ini dan terlibat pada pengalaman saat ini sehingga mempengaruhi peningkatan afek positif. Selain itu juga mindfulness mampu 110 meningkatkan kemampuan toleransi pikiran, emosi dan pengalaman sehingga mempengaruhi penurunan afek negatif.

Program "Mindful Parenting" yang diberikan dalam format kelompok memberikan manfaat positif bagi partisipan. Dalam kelompok, partisipan dapat berbagi, saling terbuka dan saling mendukung, berempati, dan belajar dari pengalaman partisipan lain.

\section{Saran}

Partisipan diharapkan dapat tetap mempraktikkan mindfulness baik secara formal dan informal secara rutin, khususnya dalam merawat anak yang mengalami retardasi mental. Partisipan dapat berkoordinasi rekan-rekan komunitas untuk melakukan meditasi bersama secara rutin.

Komunitas dapat memfasilitasi anggota yang merupakan partisipan untuk mengadakan kegiatan meditasi bersama secara rutin. Selain itu, komunitas juga dapat membuka forum diskusi pengalaman melakukan pengasuhan dengan penuh kesadaran (mindful parenting) bagi anggota komunitas.

Program "Mindful Parenting" dalam penelitian ini terbukti dapat meningkatkan kesejahteraan subjektif bagi partisipan, sehingga intervensi ini dapat digunakan oleh para psikolog/praktisi kesehatan mental untuk membantu orang tua khususnya ibu yang memiliki anak retardasi mental.

\section{Kepustakaan}

American Psychiatric Association. (2013). Diagnostic and statistical manual of mental disorders. Arlington. http://doi.org/10.1176/appi.books.978 0890425596.744053

Anderson, D., Dumont, S., Jacobs, P., \& Azzaria, L. (2007). The Personal E-JURNAL GAMA JPP 
Costs of Caring for a Child with a Disability: A Review of the Literature. Public Health Reports, 122(1), 3-16.

Baer, R. A. (2003). Mindfulness training as a clinical intervention: A conceptual and empirical review. Clinical Psychology: Science and Practice, 10, 125-143.

Baer, R. A., Smith, G. T., Hopkins, J., Krietemeyer, J., \& Toney, L. (2006). Using self-report assessment methods to explore facets of mindfulness. Assessment, 13(1), 2745.

Bazzano, A., Wolfe, C., Zylowska, L., Wang, S., Schuster, E., Barrett, C., \& Lehrer, D. (2013). Mindfulness Based Stress Reduction ( MBSR ) for Parents and Caregivers of Individuals with Developmental Disabilities: A Community-Based Approach. Journal of Child and Family Studies. 24: 298-308. http://doi.org/10.1007/s10826-0139836-9

Baker, B. L., Blacher, J., \& Olsson, M. B. (2005). Preschool children with and without developmental delay: Behaviour problems, parents' optimism and well-being. Journal of Intellectual Disability Research, 49(8), 575-590.

http://doi.org/10.1111/j.13652788.2005.00691.x

Baker, B. L., McIntyre, L. L., Blacher, J., Crnic, K., Edelbrock, C., \& Low, C. (2003). Pre-school children with and without developmental delay: Behavior problems and parenting stress over time. Journal of Intellectual Disability Research, 47(4), 217-230.

Barog, Z. S., Younesi, S. J., Sedaghati, A. H., \& Sedaghati, Z. (2015). Efficacy of mindfulness-based cognitive therapy on quality of life of mothers of children with cerebral palsy. Iranian Journal of Psychiatry, 10(2), 86-92.

Berg, R.C., Landreth, G.L., \& Fall, K.A (2006). Group counseling: concepts and procedures fourth edition. London: Routlegde.

Bernstein, N. (1990). Mothers of the retarded. Dalam Spurlock, J. \& Robinowitz. Women's Progress: Promises and Problems. Washington DC: Springer

BKKBN. 2013. Anak berkebutuhan khusus jadi perhatian BKKBN. Diakses dari http://www.bkkbn.go.id/ layouts/m obile/dispform. aspx?List=9c6767adabfe-48e3-9120af89b76d56f4\&View=174a5cf7-357b4b83-a7ac-be983c5ddb0e\&ID=844

Boehm , J. K., Lyubomirsky, S., \& Sheldon, K.M. (2011) A longitudinal experimental study comparing the effectiveness of happiness-enhancing strategies in Anglo Americans and Asian Americans. Cognition $\mathcal{E}$ Emotion, 25(7): 1263-1272.

Bögels, S., \& Restifo, K. (2014). Mindful parenting: A guide for mental health practitioners. London: Springer. http://doi.org/10.1007/978-1-46147406-7

Brown, K. W. (2015). Mindfulness Training to Enhance Positive Functioning. Dalam Brown, K. W., Creswell, J. D., \& Ryan, R. M. Handbook of Mindfulness: Theory, Research, and Practice. New York: The Guilford Press.

Brown, K. W., \& Ryan, R. M. (2003). The benefits of being present: Mindfulness and its role in psychological well-being. Journal of Personality and Social Psychology, 84(4), 822-848.

Brown, K. W., Kasser, T., Ryan, R. M., Linley, A., \& Orzech, K. (2009). When what one has is enough: 
Mindfulness, financial desire discrepancy, and subjective wellbeing. Journal of Research in Personality, 43, 727-736.

Brown, K. W., Ryan, R. M., \& Creswell, J. D. (2007). Mindfulness: Theoretical foundations and evidence for its salutary effects. Psychological Inquiry, 18(4), 211-237.

Brownstein, A. (2005) Extraordinary healing: The amazing power of your body's secret healing system. New York: Harbor Press, Inc.

Burack, J.A., Hodapp, R.M., Iarocci, G., \& Zigler, E. (2012). The Oxford handbook of intellectual disability and development. New York: Oxford Univesity Press, Inc.

Burke, M. M., \& Hodapp, R. M. (2014). Relating stress of mothers of children with developmental disabilities to family-school partnerships. Intellectual and Developmental Disabilities, 52(1), 13-23. http://doi.org/10.1352/1934-955652.1 .13

Chan, D. W. (2010). Gratitude, gratitude intervention and subjective wellbeing among Chinese school teachers in Hong Kong, Educational Psychology, 30(2), 139-153. http://doi.org/10.1080/0144341090349 3934

Coffey, K., Hartman, M., \& Fredrickson, B. (2010). Deconstructing mindfulness and constructing mental health: Understanding mindfulness and its mechanisms of action. Mindfulness, 1(4), 235-253.

Compton, W. C., \& Hoffman, E. (2013). Positive psychology: The science of happiness and flourishing, International edition. Wadsworth: Cengage Learning.
Corey, M. and Corey, G. (2014). Process and practice groups (9th ed). Belmont:Thomson Brooks/Cole.

Corey, M.S, Corey, G., Corey, C. (2013). Groups: Process and Practice. Wadsworth: Cengage Learning.

Corder, G. W., \& Foreman, D.L. (2009). Nonparametric statistics for nonstatisticians: A step by step approach. Canada: John Wiley \& Sons, Inc.

Dewanto, A. C. (2015). Pelatihan "SENANG" untuk meningkatkan kesejahteraan subjektif siswa remaja (Tesis tidak dipublikasi). Universitas Gadjah Mada, Yogyakarta.

Diener, E. (2000). Subjective well-being: the science of happiness and a proposal for a national index. American Psychologist, 55, 34-43.

Diener, E. (2009). The Science of Well-Being: The Collected Works of Ed Diener. London: Springer

Diwan, S., Chovatiya, H., \& Diwan, J. (2011). Depression and Quality of Life in Mothers of Children with Cerebral Palsy. NJIRM 2011; 2:11-13

Efklides, A., \& Moraitou, D. (2013). A positive psychology perspective on quality of life, Social indicator research series 51. London: Springer.

Emmons, R.A., \& McCullough, M.E. (2003). Counting blessings versus burdens: An experimental investigation of gratitude and subjective well-being in daily life. Journal of Personality and Social Psychology. 84(2): 377-389.

Falkenstrom, F. (2010). Studying mindfulness in experienced mediators: A quasiexperimental approach. Personality and Individual Differences, 48, 305-310.

Findler, L., Klein Jacoby, A., \& Gabis, L. (2016). Subjective happiness among mothers of children with disabilities: The role of stress, attachment, guilt 
and social support. Research in Developmental Disabilities, 55, 44-54. http://doi.org/10.1016/j.ridd.2016.03.0 06

Gardiner, E., \& Iarocci, G. (2012). Unhappy (and happy) in their own way: A developmental psychopathology perspective on quality of life for families living with developmental disability with and without autism. Research in Developmental Disabilities, 33(6),

2177-2192.

http://doi.org/10.1016/j.ridd.2012.06.0 14

Germer, C. K., Siegel, R. D., \& Fulton, P. R. (2005). Mindfulness and psychotherapy. New York: Guilford Press.

Glenn, S., Cunningham, C., Poole, H., Reeves, D., \& Weindling, M. (2009). Maternal parenting stress and its correlates in families with a young child with cerebral palsy. Child: Care, Health and Development, 35(1), 71-78. http://doi.org/10.1111/j.1365-

2214.2008.00891.x

Hallahan, D.P., Kauffman, J.M. and Pullen, P.C. (2012). Exceptional learners. An introduction to special education. New Jersey: Pearson.

Hanley, A., Warner, A., \& Garland, E. L. (2015). Associations Between Mindfulness, Psychological WellBeing, and Subjective Well-Being with Respect to Contemplative Practice. Journal of Happiness Studies, 16(6), 1423-1436. http://doi.org/10.1007/s10902-0149569-5

Isa, S. N., Aziz, A. A., Rahman, A. A., Ibrahim, M. I., Ibrabim, W. P., Mohamad, N., et al. (2013). The impact of disabled children on parent health-related quality of life and family functioning in Kelantan and its associated factors. Journal of
Developmental and Behavioral Pediatrics, 34, 262-268.

Jackowska, M., Brown, J., Ronaldson, A., \& Steptoe, A. (2015). The impact of a brief gratitude intervention on subjective well-being, biology and sleep. Journal of Health Psychology. http://doi.org/10.1177/1359105315572 455

Johnson, L.A., \& Caldwell, B.E. (2010). Race, gender, and therapistconfidence: effects on satisfaction with therapeutic relationship in MFT. American Journal of Family Therapy, 39, 307-324.

Kabat-Zinn, J. (1994). Wherever you go, there you are: Mindfulness meditation in everyday life. New York: Hyperion.

Kabat-Zinn, J. (2013). Full catatrophe living (revised edition): Using the wisdom of your body and mind to face stress, pain, and illness. Bantam: Delta.

Kaviani H. J. F., \& Hatami N. MindfulnessBased Cognitive Therapy (MBCT) reduces depression and anxiety induced by real stressful setting in non-clinical population. International Journal of Psychology and Psychological Therapy. 2011; 11: 285-296.

Kemkes RI. (2014). Penyandang Disabilitas Anak. Infodatin : Pusat Informasi Kementrian Kesehatan RI. Diakses dari http://www.kemkes.go.id/resources/ download/pusdatin/infodatin/infoda tin_disabilitas.pdf

Kogan, M. D., Strickland, B. B., Blumberg, S. J., Singh, G. K., Perrin, J. M., \& van Dyck, P. C. (2008). A national profile of the health care experiences and family impact of autism spectrum disorder among children in the United States, 2005-2006. Pediatrics, 122, e1149-e1158.

Lane, J. B., Goodrich, E., \& Miller, M. (2015). One-on-one Mindfulness Meditation Trainings in a Research 
Setting . Mindfulness, , 5(1), 88-99. http://doi.org/10.1007/s12671-0120155-9.

Lee, J. (2013). Maternal stress, well-being, and impaired sleep in mothers of children with developmental disabilities: A literature review. Research in Developmental Disabilities, 34(11), 4255-4273. http://doi.org/10.1016/j.ridd.2013.09.0 08

Malaktaris, A., Lemons, P., Lynn, S. J., Condon, L. (2015). Chilling Out: Meditation, Relaxation, and Yoga. Dalam Lynn, S. J., O'Donohue, W. T., \& Lilienfeld, S. O (Eds). Health, happiness, and well-being: Better living through psychological science. London:Sage Publications, Inc.

Mehranfar, M., Younesi, J., \& Banihashem A. (2012). Effectiveness of Mindfulness-Based Cognitive Therapy on Reduction of Depression and Anxiety Symptoms in Mothers of Children With Cancer. Iranian Journal of Cancer Prevention. 5: 1-10.

Norlin, D., \& Broberg, M. (2013). Parents of children with and without intellectual disability: Couple relationship and individual wellbeing. Journal of Intellectual Disability Research, 57(6), 552-566. http://doi.org/10.1111/j.13652788.2012.01564.x

Olsson M. B. \& Hwang. C. P. (2001). Depression in mothers and fathers of children with intellectual disability. Journal of Intellectual Disability Research 45, 535-43.

Olsson, M. B., \& Hwang, C. P. (2006). Wellbeing, involvement in paid work and division of child-care in parents of children with intellectual disabilities in Sweden. Journal of Intellectual Disability Research, 50(12), 963-969. http://doi.org/10.1111/j.1365- 2788.2006.00930.x

Reichman, N. E., Corman, H., \& Noonan, K. (2008). Impact of Child Disability on the Family. Maternal Child Helath Journal. 12: 679-683. http://doi.org/10.1007/s10995-0070307-z

Rosada. A. (2015). Emphatic love therapy untuk meningkatkan kesejahteraan subjektif dan kesiapan guru di sekolah inklusi. (Tesis tidak dipublikasi). Universitas Gadjah Mada, Yogyakarta.

Schieve, L. A., Boulet, S. L., Kogan, M. D., Van Naarden-Braun, K., \& Boyle, C. A. (2011). A population-based assessment of the health, functional status, and consequent family impact among children with Down syndrome. Disability and Health Journal, 4, 68-77.

Schroevers, M. J., Tovote, K. A., Snippe, E., \& Fleer, J. (2016). Group and Individual Mindfulness-Based Cognitive Therapy ( MBCT ) Are Both Effective: a Pilot Randomized Controlled Trial in Depressed People with a Somatic Disease. Mindfulness, 1339-1346.

http://doi.org/10.1007/s12671-0160575-z

Shapiro, S.L., Carlson, L.E., Austin, J.A., \& Freedman, B. (2006). Mechanisms of mindfulness. Journal of Clinical Psychology, 62, 373-386.

Shapiro, S. L., \& Carlson, L. E. (2009). The art and science of mindfulness: Integrating mindfulness into psychology and helping professions. Washington DC: American Psychological Association.

Singer, G. H. S. (2006). Meta-Analysis of Comparative Studies of Depression in Mothers of Children With and Without Developmental Disabilities. American Association Mental 
Retardation American Journal On Mental Retardation, 155(3), 155-169. http://doi.org/10.1352/08958017(2006)111[155:MOCSOD]2.0.CO; 2

Smith, L. E., Greenberg, J. S., \& Seltzer, M. M. (2012). Social support and wellbeing at mid-life among mothers of adolescents and adults with autism spectrum disorders. Journal of Autism and Developmental Disorders, 42(9), $1818-1826$.

http://doi.org/10.1007/s10803-0111420-9

Stahl, B., \& Goldstein, E. (2010). A mindfulness-based stress reduction workbook. Oakland: New Harbinger Publications, Inc.

Sturmey, P., \& Didden, R. (2014). Evidencebased practice and intellectual disabilities. West Sussex: John Wiley \& Sons, Ltd.

Totsika, V., Hastings, R. P., Emerson, E., Berridge, D. M., \& Lancaster, G. A. (2011). Behavior problems at 5 years of age and maternal mental health in autism and intellectual disability. Journal of Abnormal Child Psychology, 39(8), 1137-1147. http://doi.org/10.1007/s10802-0119534-2

Tyas, M.P. (2015). Terapi pemaafan untuk meningkatkan kesejahteraan subjektif istri yang berkonflik dengan suami. (Tesis tidak dipublikasi). Universitas Gadjah Mada, Yogyakarta.

Watson, D., Clark, L. A., \& Tellegen, A. (1988). Development and validation of brief measures of positive and negative affect: The PANAS scales. Journal of Personality and Social Psychology, 54, 1063-1070.

WHO. (2011). World Report on Disability 2011. American Journal of Physical Medicine Rehabilitation Association of Academic Physiatrists, 91, 549. http://doi.org/10.1136/ip.2007.018143

Yalom, I.D. \& Leszcz, M. (2005). The theory and practice of group psychotherapy. New York: Basic Books, Inc Publisher 